-Journal Publications • Research Consultancy

\title{
DEMYSTIFYING BIG DATA ANALYTICS TECHNIQUES
}

\section{KOMALPREET KAUR ${ }^{1}$, CHITENDER KAUR ${ }^{2}$ \& TARANDEEP KAUR BHATIA ${ }^{\mathbf{3}}$}

${ }^{1}$ Research Scholar, Department of Computer Science \& Engineering, Chandigarh Engineering College,

\author{
Landran, Punjab, India
}

${ }^{2}$ Assistant Professor, Department of Computer Science \& Engineering, Chandigarh Engineering College,

Landran, Punjab, India

${ }^{3}$ Assistant Professor, Department of Computer Science \& Engineering, Chitkara University, Punjab, India

\begin{abstract}
Big Data is relevant for massive amounts of data that do not have the potential to be managed by the traditional information processing techniques. This paper sights on introducing the term big data and illustrating various big data analytics techniques along with its benefits, bottlenecks and application areas that can be helpful in addressing the big data issues.
\end{abstract}

KEYWORDS: Big Data, Big Data Analytics, Sentiment Analysis \& Neural Networks

Received: Jan 24, 2019; Accepted: Feb 14, 2019; Published: Mar 01, 2018; Paper Id.: IJCNWMCJUN20193

\section{INTRODUCTION}

"BIG DATA" - a term representing vast and huge datasets with varying types of data and complex data structures having difficulties in storing, processing, analysing and retrieving information for generating the results [1]. Big data is of great significance to create profitable ventures in businesses and provides innumerable opportunities to achieve remarkable progress in various fields. In comparison to traditional datasets, big data mainly includes unstructured type of data that requires a thorough real-time analysis [2]. The procedure of analysing huge amounts of data to uncover the underlying patterns and connections is termed as big data analytics. These valuable information helps the organizations for gaining better insights and getting benefits over the competitive organizations [3]. For this reason, a precise analysis of big data is to be done.

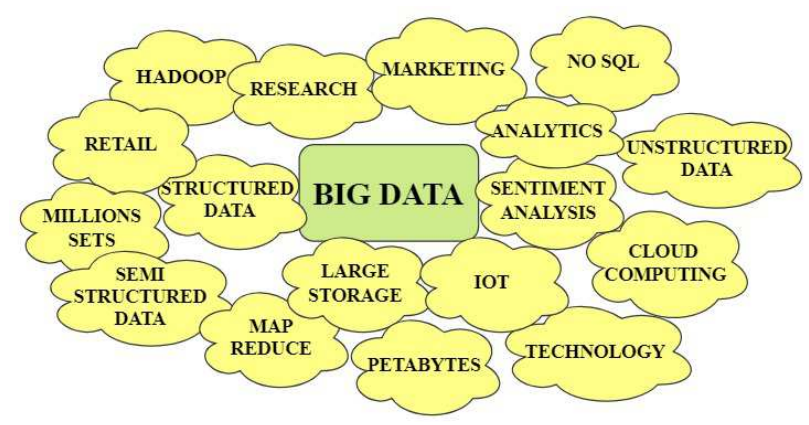

Figure 1: Big Data Concepts

\section{LITERATURE REVIEW}

Data analytics is a way of organizing big data. There are distinct patterns and inter-relationships within big data that helps data analytics to gain better insights regarding the characteristics of data. Thus, data analytics is the 
most vital component of information technology.

Peter et al. [4] has discussed about various optimization methods for solving the optimization problems. These methods produce the solutions in a timely manner but consumes a great space in memory. Moreover, the authors have also mentioned the application areas for these methods such as biology, physics.

Chen et al. [5] has presented statistics by gathering the data and arranging it in such a manner that the underlying relationship between variables are explored. This has also been found that this technique is not appropriate for managing data in a better way. Many applications in the field of medicine and science have also been stated.

Hand et al. [6] has studied about data mining by performing thorough analysis on extensive datasets and also showed that this information has helped in predicting market trends in future to a great extent. The authors have also considered methods by which the data can be used for unethical purposes.

Pang et al. [7] has used various statistical methods to get a better understanding of machine learning concepts. The techniques have been discussed for making the computers capable of learning and acting along with utilization of resources in an efficient manner.

Potter et al. [8] has examined visualization approaches for generating diagrams, graphs and table to ease the analysis process of data. But, the authors have also shown that different users have different point of views which may produce inefficient results.

George et al. [9] has discussed about methods for comparing between two versions of an application. The authors have shown very effortless and easy analysis for performing A/B testing but have observed that this technique focuses on quantity only.

Lina et al. [10] has presented association learning methods for defining associations among the variables. The authors have also found that implementation of this technique is simple but not appropriate for large databases.

Lemon et al. [11] has described methods for making classifications regarding the categories to which observations belong. This technique turned out to be very complicated and unreliable for the authors. The authors has taken the example of predicting the type of soil in deserts.

Wilks et al. [12] has examined the work for cluster analysis by grouping the same objects in a cluster. The authors have shown the use of this technique for illustrating the hidden connections and also its contribution in the field of data mining.

Doan et al. [13] has discussed about crowd sourcing by assigning a task of journalism to the general public rather than any professional thus saving money greatly. But the authors have proved that because of the involvement of a large number of users, confidentiality is compromised.

Rosen et al. [14] has combined ensemble learning algorithms for obtaining better results and enhancing the stability of the system. The face recognition example has been thoroughly taken into account by the authors.

Whitley et al. [15] has described genetic algorithms for finding certain or approximate solutions for problems. But, huge amount of time has been taken for performing computations by the authors. The tasks related to pattern matching have been discussed. 
Jain et al. [16] has explored interactions between the users and the system by manipulating natural languages such as text. The authors have used user- friendly techniques for faster processing and for performing sentiment analysis on huge dataset.

Liu et al. [17] has reviewed the way of processing information by neural networks that are inspired by the human brain. Apart from this, the authors have reported the difficulty in representing the problem to the network and dependency on hardware.

Fagan et al. [18] has focused on pattern recognition methods that requires human input. The deviations in the patterns have been taken into account by the authors. Moreover, the authors have undertaken example of stock markets for a better understanding of this technique.

Einav et al. [19] has analysed predictive modelling techniques for speculating the outcomes. The authors have explained the use of this method for implementing business strategies to achieve long term benefits but along with frequent updating in the systems.

DeFries et al. [20] has studied regression analysis by predicting the relationship between dependent variables and independent variables. The authors have used the fields of engineering, sales and economics to generate highly accurate results.

Agarwal et al. [21] has discussed about the methods for analysis of sentiments of users. Focus on improving the customer services and managing the crisis in an effective manner have been discussed by the authors. The authors have taken the examples of social networking sites.

Sandryhaila et al. [22] has manipulated the information in signals to convert into meaningful data. Authors have used cost- efficient methods for making the required changes in the program, but reported that synchronizing the systems for communication became a bottleneck.

Anselin et al. [23] has examined spatial analysis based on the conversion of data into useful information and identification of attributes in spatial data. The authors have shown in their work that requires of prior knowledge generated a lot of errors in the selection of sites.

Nadeau et al. [24] has described supervised learning techniques taking place under the supervision of a teacher. The authors have presented this technique as a highly specific one, but also stated that a lot of time was taken for performing the computations and training the network.

Table 1: Big Data Analytics Techniques

\begin{tabular}{|c|l|l|l|l|l|}
\hline $\begin{array}{c}\text { Sr. } \\
\text { No }\end{array}$ & \multicolumn{1}{|c|}{$\begin{array}{c}\text { Name of the } \\
\text { Technique }\end{array}$} & \multicolumn{1}{|c|}{ Description } & \multicolumn{1}{|c|}{ Advantage } & \multicolumn{1}{c|}{ Disadvantage } & $\begin{array}{l}\text { Application } \\
\text { Area }\end{array}$ \\
\hline 1. & $\begin{array}{l}\text { Optimization } \\
\text { methods[4] }\end{array}$ & $\begin{array}{l}\text { Provides several } \\
\text { strategies for } \\
\text { computations and } \\
\text { handling optimization } \\
\text { problems. }\end{array}$ & $\begin{array}{l}\text { Generates } \\
\text { solutions for } \\
\text { quantitative } \\
\text { problems in } \\
\text { minimal time. }\end{array}$ & $\begin{array}{l}\text { Complexity in } \\
\text { memory is high. }\end{array}$ & $\begin{array}{l}\text { Speech, text } \\
\text { processing, } \\
\text { biology, } \\
\text { physics }\end{array}$ \\
\hline 2. & Statistics[5] & $\begin{array}{l}\text { Science that deals with } \\
\text { collection and } \\
\text { organization of data } \\
\text { along with interpretation } \\
\text { of results. }\end{array}$ & $\begin{array}{l}\text { Explores the } \\
\text { causal } \\
\text { relationships } \\
\text { among different } \\
\text { variables. }\end{array}$ & $\begin{array}{l}\text { Traditional statistical } \\
\text { techniques are not } \\
\text { appropriate for the } \\
\text { well management of } \\
\text { big data. }\end{array}$ & $\begin{array}{l}\text { Scientific } \\
\text { databases, } \\
\text { Medical } \\
\text { records. }\end{array}$ \\
\hline
\end{tabular}




\begin{tabular}{|c|c|c|c|c|c|}
\hline 3. & Data mining[6] & $\begin{array}{l}\text { Process of analyzing } \\
\text { large datasets for } \\
\text { identifying the hidden } \\
\text { patterns and relationships } \\
\text { that are useful in solving } \\
\text { a problem. }\end{array}$ & $\begin{array}{l}\text { Helpful in } \\
\text { predicting the } \\
\text { future trends in } \\
\text { the markets. }\end{array}$ & $\begin{array}{l}\text { Data gathered } \\
\text { through this } \\
\text { technique for ethical } \\
\text { motives can be } \\
\text { fraudulently used. }\end{array}$ & $\begin{array}{l}\text { Marketing, } \\
\text { healthcare, } \\
\text { medical } \\
\text { science, } \\
\text { banking, } \\
\text { sales. }\end{array}$ \\
\hline 4. & $\begin{array}{l}\text { Machine } \\
\text { learning[7] }\end{array}$ & $\begin{array}{l}\text { Science that uses } \\
\text { statistical methods for } \\
\text { providing ability to act } \\
\text { and learn to the } \\
\text { computers without } \\
\text { programming explicitly. }\end{array}$ & $\begin{array}{l}\text { Capability of } \\
\text { handling } \\
\text { heterogeneous } \\
\text { data and utilizing } \\
\text { the resources } \\
\text { efficiently. }\end{array}$ & $\begin{array}{l}\text { Acquisition is the } \\
\text { main challenge } \\
\text { associated with this } \\
\text { technique. Data need } \\
\text { to be thoroughly } \\
\text { analyzed and } \\
\text { processed before } \\
\text { serving it as input to } \\
\text { the given algorithm. }\end{array}$ & $\begin{array}{l}\text { Extracting } \\
\text { data from } \\
\text { social } \\
\text { networking } \\
\text { websites, } \\
\text { discovery of } \\
\text { drugs, } \\
\text { diagnosis in } \\
\text { medical } \\
\text { science, } \\
\text { speech } \\
\text { recognition. }\end{array}$ \\
\hline 5 . & $\begin{array}{l}\text { Visualization } \\
\text { approaches[8] }\end{array}$ & $\begin{array}{l}\text { Used in the creation of } \\
\text { images, tables and } \\
\text { generating diagrams, } \\
\text { graphs to get better } \\
\text { insights into data. }\end{array}$ & $\begin{array}{l}\text { Provides quick } \\
\text { access to business } \\
\text { activities for } \\
\text { better } \\
\text { understanding of } \\
\text { future trends. } \\
\end{array}$ & $\begin{array}{l}\text { Different users have } \\
\text { different perceptions } \\
\text { and this sometimes } \\
\text { results in inaccurate } \\
\text { results. }\end{array}$ & $\begin{array}{l}\text { Retail } \\
\text { marketing, } \\
\text { cognition, } \\
\text { apprehension. }\end{array}$ \\
\hline 6. & A/B Testing[9] & $\begin{array}{l}\text { Method of drawing } \\
\text { comparison between two } \\
\text { versions of an } \\
\text { application or a web } \\
\text { page to conclude which } \\
\text { performs better. } \\
\text { Also known as split } \\
\text { testing. }\end{array}$ & $\begin{array}{l}\text { Provides effortless } \\
\text { analysis and is } \\
\text { multifunctional. }\end{array}$ & $\begin{array}{l}\text { Speed is slow and is } \\
\text { cost - ineffective. } \\
\text { Moreover, focuses } \\
\text { only on quantity and } \\
\text { not quality. }\end{array}$ & $\begin{array}{l}\text { Marketing, } \\
\text { statistics, data } \\
\text { analytics. }\end{array}$ \\
\hline 7. & $\begin{array}{l}\text { Association rule } \\
\text { learning[10] }\end{array}$ & $\begin{array}{l}\text { Determines the } \\
\text { relationships, that is, } \\
\text { associations among } \\
\text { different variables } \\
\text { existing in large } \\
\text { databases. }\end{array}$ & $\begin{array}{l}\text { Scanning the } \\
\text { repeated database } \\
\text { is discarded, } \\
\text { implementation is } \\
\text { simple. }\end{array}$ & $\begin{array}{l}\text { Suitable for only } \\
\text { small databases, } \\
\text { consumption of } \\
\text { memory is large. }\end{array}$ & $\begin{array}{l}\text { Market } \\
\text { basket } \\
\text { analysis } \\
\text { dealing with } \\
\text { the behaviors } \\
\text { of customer } \\
\text { purchases. }\end{array}$ \\
\hline 8. & $\begin{array}{l}\text { Classification tree } \\
\text { analysis[11] }\end{array}$ & $\begin{array}{l}\text { Method of determining } \\
\text { the category to which a } \\
\text { new observation belongs } \\
\text { to. }\end{array}$ & $\begin{array}{l}\text { Easy to use, } \\
\text { transparent and } \\
\text { specific. }\end{array}$ & $\begin{array}{l}\text { Expensive, } \\
\text { complicated and } \\
\text { unreliable. }\end{array}$ & $\begin{array}{l}\text { Predicting the } \\
\text { type of soil in } \\
\text { the desert, } \\
\text { making } \\
\text { student } \\
\text { profiles who } \\
\text { opt for online } \\
\text { courses. }\end{array}$ \\
\hline 9. & $\begin{array}{l}\text { Cluster analysis } \\
{[12]}\end{array}$ & $\begin{array}{l}\text { Statistical tool for } \\
\text { classification of objects } \\
\text { into clusters, that is, } \\
\text { groups in such a manner } \\
\text { that all the objects that } \\
\text { are similar to each other } \\
\text { belong to the same } \\
\text { group. }\end{array}$ & $\begin{array}{l}\text { As it groups the } \\
\text { similar objects } \\
\text { together, therefore } \\
\text { this technique is } \\
\text { useful in } \\
\text { identifying the } \\
\text { patterns between } \\
\text { the objects. }\end{array}$ & $\begin{array}{l}\text { Difficulty in } \\
\text { determining the } \\
\text { number of clusters } \\
\text { that are needed for } \\
\text { analysis. }\end{array}$ & $\begin{array}{l}\text { Exploratory } \\
\text { research, data } \\
\text { mining. }\end{array}$ \\
\hline 10. & Crowdsourcing[13] & $\begin{array}{l}\text { A task, obtained from } \\
\text { outside, is assigned to } \\
\text { general public rather }\end{array}$ & $\begin{array}{l}\text { Cost- effective, } \\
\text { diversification in } \\
\text { experienced }\end{array}$ & $\begin{array}{l}\text { Confidentiality is at } \\
\text { risk as a large group } \\
\text { is involved in testing. }\end{array}$ & $\begin{array}{l}\text { Astronomy, } \\
\text { journalism, } \\
\text { schedule of }\end{array}$ \\
\hline
\end{tabular}




\begin{tabular}{|c|c|c|c|c|c|}
\hline & & $\begin{array}{l}\text { than any professional or } \\
\text { an organization. }\end{array}$ & $\begin{array}{l}\text { because of the } \\
\text { involvement of } \\
\text { large number of } \\
\text { users. }\end{array}$ & $\begin{array}{l}\text { Moreover, time and } \\
\text { language barriers can } \\
\text { make the } \\
\text { communication } \\
\text { between testers a bit } \\
\text { tedious work. }\end{array}$ & events. \\
\hline 11. & $\begin{array}{l}\text { Ensemble learning } \\
{[14]}\end{array}$ & $\begin{array}{l}\text { Combines different types } \\
\text { of algorithms that are } \\
\text { devised for learning so to } \\
\text { enhance the stability of } \\
\text { the model. }\end{array}$ & $\begin{array}{l}\text { This technique } \\
\text { can be effectively } \\
\text { parallelized, thus } \\
\text { enhancing the } \\
\text { system } \\
\text { performance. }\end{array}$ & $\begin{array}{l}\text { In case the ensemble } \\
\text { method chosen, is } \\
\text { not appropriate } \\
\text { according to the } \\
\text { setting, then } \\
\text { performance will } \\
\text { decline } \\
\text { automatically. }\end{array}$ & $\begin{array}{l}\text { Detecting } \\
\text { frauds, } \\
\text { system } \\
\text { security, face } \\
\text { recognition. }\end{array}$ \\
\hline 12. & $\begin{array}{l}\text { Genetic algorithms } \\
{[15]}\end{array}$ & $\begin{array}{l}\text { Search techniques } \\
\text { applied in soft } \\
\text { computing to determine } \\
\text { the certain or } \\
\text { approximate solutions } \\
\text { for search problems }\end{array}$ & $\begin{array}{l}\text { In case of hybrid } \\
\text { applications, it } \\
\text { can form blocks } \\
\text { flexibly. } \\
\text { Moreover, it is } \\
\text { simple to } \\
\text { understand. }\end{array}$ & $\begin{array}{l}\text { Slower than other big } \\
\text { data techniques as it } \\
\text { takes more time for } \\
\text { performing } \\
\text { computations. }\end{array}$ & $\begin{array}{l}\text { Training } \\
\text { neural } \\
\text { networks, } \\
\text { performing } \\
\text { tasks related } \\
\text { to image } \\
\text { processing } \\
\text { like pattern } \\
\text { matching. } \\
\end{array}$ \\
\hline 13. & $\begin{array}{l}\text { Natural Language } \\
\text { Processing[16] }\end{array}$ & $\begin{array}{l}\text { Deals with manipulating } \\
\text { natural languages such as } \\
\text { speech, text } \\
\text { automatically by using } \\
\text { software. } \\
\text { It is basically concerned } \\
\text { with system and human } \\
\text { interactions. }\end{array}$ & $\begin{array}{l}\text { User - friendly, } \\
\text { processing is fast, } \\
\text { infers solutions } \\
\text { that are not } \\
\text { generated before. }\end{array}$ & $\begin{array}{l}\text { Precision and } \\
\text { machine translation } \\
\text { are major limitations } \\
\text { of natural language } \\
\text { processing. }\end{array}$ & $\begin{array}{l}\text { Sentiment } \\
\text { analysis, } \\
\text { classifying } \\
\text { the text, } \\
\text { summarizing } \\
\text { content, } \\
\text { question } \\
\text { answering. }\end{array}$ \\
\hline 14. & $\begin{array}{l}\text { Neural networks } \\
{[17]}\end{array}$ & $\begin{array}{l}\text { Information processing } \\
\text { technique influenced by } \\
\text { the way information is } \\
\text { processed by brain. }\end{array}$ & $\begin{array}{l}\text { Fault - tolerant, } \\
\text { can work with } \\
\text { incomplete } \\
\text { information. }\end{array}$ & $\begin{array}{l}\text { Unpredictable } \\
\text { behavior of network } \\
\text { makes it difficult to } \\
\text { represent problem to } \\
\text { network, dependence } \\
\text { on hardware. }\end{array}$ & $\begin{array}{l}\text { Face } \\
\text { recognition, } \\
\text { speech } \\
\text { recognition, } \\
\text { and character } \\
\text { recognition. }\end{array}$ \\
\hline 15. & $\begin{array}{l}\text { Pattern recognition } \\
{[18]}\end{array}$ & $\begin{array}{l}\text { Section of machine } \\
\text { learning that focuses on } \\
\text { the recognition of } \\
\text { patterns or deviations in } \\
\text { a particular scenario. }\end{array}$ & $\begin{array}{l}\text { Transparency is } \\
\text { the merit of } \\
\text { pattern } \\
\text { recognition. Also, } \\
\text { implemented } \\
\text { manually with a } \\
\text { great ease. }\end{array}$ & $\begin{array}{l}\text { Human input is } \\
\text { required, faces } \\
\text { difficulty in case of } \\
\text { complex datasets. }\end{array}$ & $\begin{array}{l}\text { Forecasting } \\
\text { stock } \\
\text { markets, } \\
\text { categorization } \\
\text { of rocks, } \\
\text { analyzing and } \\
\text { controlling } \\
\text { traffic. } \\
\end{array}$ \\
\hline 16. & $\begin{array}{l}\text { Predictive } \\
\text { modelling[19] }\end{array}$ & $\begin{array}{l}\text { Statistical technique for } \\
\text { predicting future } \\
\text { behavior. } \\
\text { This technique uses } \\
\text { probability and data } \\
\text { mining to speculate } \\
\text { outcomes. }\end{array}$ & $\begin{array}{l}\text { Useful for } \\
\text { business strategies } \\
\text { in terms of taking } \\
\text { decisions related } \\
\text { to launching a } \\
\text { new product in the } \\
\text { market. }\end{array}$ & $\begin{array}{l}\text { Requires updating of } \\
\text { the model as the } \\
\text { customer behavior } \\
\text { varies with time. }\end{array}$ & $\begin{array}{l}\text { Online } \\
\text { marketing, } \\
\text { advertising, } \\
\text { weather } \\
\text { forecasting, } \\
\text { meteorology. }\end{array}$ \\
\hline
\end{tabular}




\begin{tabular}{|c|c|c|c|c|c|}
\hline 17. & $\begin{array}{l}\text { Regression } \\
\text { analysis[20] }\end{array}$ & $\begin{array}{l}\text { Models the relationship } \\
\text { between predictor } \\
\text { variables and response } \\
\text { variable. } \\
\text { It describes how } \\
\text { independent variables } \\
\text { influences the dependent } \\
\text { variables. }\end{array}$ & $\begin{array}{l}\text { Results are highly } \\
\text { accurate, uses } \\
\text { multiple variables } \\
\text { for gaining better } \\
\text { insights. }\end{array}$ & $\begin{array}{l}\text { Procedure for } \\
\text { analysis and } \\
\text { computations is } \\
\text { complex and time } \\
\text { consuming, not } \\
\text { applicable for } \\
\text { qualitative } \\
\text { phenomena such as } \\
\text { intelligence, honesty. }\end{array}$ & $\begin{array}{l}\text { Engineering, } \\
\text { economics, } \\
\text { business } \\
\text { sales. }\end{array}$ \\
\hline 18. & $\begin{array}{l}\text { Sentiment analysis } \\
{[21]}\end{array}$ & $\begin{array}{l}\text { Method of determining } \\
\text { the sentiments, that is, } \\
\text { view or opinion of a } \\
\text { person, writer or speaker } \\
\text { on a particular topic. }\end{array}$ & $\begin{array}{l}\text { Enhanced } \\
\text { customer service, } \\
\text { crisis are managed } \\
\text { effectively. }\end{array}$ & $\begin{array}{l}\text { Details like hilarity, } \\
\text { anger, sarcasm are } \\
\text { hardly noticeable } \\
\text { using sentiment } \\
\text { analysis. }\end{array}$ & $\begin{array}{l}\text { Monitoring } \\
\text { social media, } \\
\text { exploiting } \\
\text { unstructured } \\
\text { data in } \\
\text { business. }\end{array}$ \\
\hline 19. & $\begin{array}{l}\text { Signal processing } \\
{[22]}\end{array}$ & $\begin{array}{l}\text { Manipulates the } \\
\text { information in signals to } \\
\text { simplify the speech } \\
\text { recognition. } \\
\text { It retrieves the } \\
\text { information from speech } \\
\text { and convert it into } \\
\text { meaningful words. }\end{array}$ & $\begin{array}{l}\text { Cost- efficient, } \\
\text { processing } \\
\text { operations can be } \\
\text { changed by } \\
\text { making changes in } \\
\text { the program. }\end{array}$ & $\begin{array}{l}\text { Proper } \\
\text { synchronization of } \\
\text { communication } \\
\text { system becomes a } \\
\text { major issue of this } \\
\text { technique. }\end{array}$ & $\begin{array}{l}\text { Seismology, } \\
\text { biomedical } \\
\text { engineering, } \\
\text { control } \\
\text { systems, } \\
\text { audio } \\
\text { processing. }\end{array}$ \\
\hline 20. & $\begin{array}{l}\text { Spatial analysis } \\
{[23]}\end{array}$ & $\begin{array}{l}\text { Process of converting } \\
\text { raw data into meaningful } \\
\text { information. It is based } \\
\text { on the identification of } \\
\text { the location and } \\
\text { attributes of spatial data. }\end{array}$ & $\begin{array}{l}\text { Enhanced } \\
\text { customer service, } \\
\text { improved } \\
\text { productivity, more } \\
\text { efficient. }\end{array}$ & $\begin{array}{l}\text { Requires prior } \\
\text { knowledge and may } \\
\text { generate a large } \\
\text { number of errors. }\end{array}$ & $\begin{array}{l}\text { Selection of } \\
\text { sites, } \\
\text { Visualization } \\
\text { approaches. }\end{array}$ \\
\hline 21. & $\begin{array}{l}\text { Supervised } \\
\text { learning[24] }\end{array}$ & $\begin{array}{l}\text { In supervised learning } \\
\text { there is a teacher, under } \\
\text { whose supervision, } \\
\text { learning takes place. The } \\
\text { input is given to network } \\
\text { and corresponding output } \\
\text { is generated which is } \\
\text { then compared with } \\
\text { desired output. }\end{array}$ & $\begin{array}{l}\text { Extremely } \\
\text { accurate as it is } \\
\text { very specific in } \\
\text { defining the } \\
\text { variables. }\end{array}$ & $\begin{array}{l}\text { A lot of computation } \\
\text { time is needed for } \\
\text { training the network. }\end{array}$ & $\begin{array}{l}\text { Pattern, } \\
\text { speech and } \\
\text { handwriting } \\
\text { recognition, } \\
\text { database } \\
\text { marketing. }\end{array}$ \\
\hline
\end{tabular}

\section{CONCLUSIONS}

The entrance into the age of big data has already taken place, which is the upcoming frontier in terms of innovation and productivity. This review paper provides a view of big data, including big data concepts. The big data analytics techniques are explored for solving the big data problems. Although some of the techniques are still not well established, but in the upcoming time these techniques will definitely face great advancements.

\section{FUTURE SCOPE}

The inception of big data unfolds incredible opportunities. During the IT period, technology was the major concern which leads to the generation of data. In the big data period, the worth of data will lead to the advancement of technologies in the near future. Big data will not just influence socially and economically in a positive way, but it will also impact everyone's way of thinking for one's benefit. Big data analytics will integrate into prospering market, thus providing boundless opportunities to the organizations and researchers. Moreover, with advanced technologies like Internet of Things (IOT), machine leaning, the future of big data is going to be unshakeable. 


\section{REFERENCES}

1. Michael, Katina, and Keith W. Miller. "Big data: New opportunities and new challenges [guest editors' introduction]." Computer 46, no. 6 (2013): 22-24.

2. Boyd, Danah, and Kate Crawford. "Critical questions for big data: Provocations for a cultural, technological, and scholarly phenomenon." Information, communication \& society 15, no. 5 (2012): 662-679.

3. Gandomi, Amir, and Murtaza Haider. "Beyond the hype: Big data concepts, methods, and analytics." International Journal of Information Management 35, no. 2 (2015): 137-144.

4. Richtárik, Peter, and Martin Takáč. "Parallel coordinate descent methods for big data optimization." Mathematical Programming 156, no. 1-2 (2016): 433-484.

5. Chen, James J., Eric Evan Chen, Weizhong Zhao, and Wen Zou. "Statistics in Big Data." Vol 53, no. 3 (2015): 186-202.

6. Hand, David J. "Principles of data mining." Drug safety 30, no. 7 (2007): 621-622.

7. Pang, Bo, Lillian Lee, and Shivakumar Vaithyanathan. "Thumbs up?: sentiment classification using machine learning techniques." In Proceedings of the ACL-02 conference on Empirical methods in natural language processing-Volume 10, pp. 79-86. Association for Computational Linguistics, 2002.

8. Chang, W. Y., \& Chang, P. C. (2017). Application of Radial Basis Function Neural Network, to Estimate the State of Health for LFP Battery.

9. Potter, Kristin, Paul Rosen, and Chris R. Johnson. "From quantification to visualization: A taxonomy of uncertainty visualization approaches." In Uncertainty Quantification in Scientific Computing, pp. 226-249. Springer, Berlin, Heidelberg, 2012.

10. George, Gerard, Martine R. Haas, and Alex Pentland. "Big data and management." (2014): 321-326.

11. Lina, Lu, Chen Yaping, Yang Maishun, and Wei Hengyi. "Algorithm Optimization of Mining Association Rules [J]." COMPUTER ENGINEERING AND APPLICATIONS 8 (2000): 031.

12. Lemon, Stephenie C., Jason Roy, Melissa A. Clark, Peter D. Friedmann, and William Rakowski. "Classification and regression tree analysis in public health: methodological review and comparison with logistic regression." Annals of behavioral medicine 26, no. 3 (2003): 172-181.

13. Wilks, Daniel S. "Cluster analysis." In International geophysics, vol. 100, pp. 603-616. Academic press, 2011.

14. Doan, Anhai, Raghu Ramakrishnan, and Alon Y. Halevy. "Crowdsourcing systems on the world-wide web." Communications of the ACM 54, no. 4 (2011): 86-96.

15. Mengistu, A. D., \& Alemayehu, D. M. (2016). Robot for visual object tracking based on artificial neural network. International Journal of Robotics Research and Development (IJRRD), 6(1), 1-6.

16. Rosen, Bruce E. "Ensemble learning using decorrelated neural networks." Connection science 8, no. 3-4 (1996): 373-384.

17. Whitley, Darrell. "A genetic algorithm tutorial." Statistics and computing 4, no. 2 (1994): 65-85.

18. Jain, Aditya, Gandhar Kulkarni, and Vraj Shah. "Natural language processing." International Journal of Computer Sciences and Engineering 6, no. 1 (2018).

19. Liu, Weibo, Zidong Wang, Xiaohui Liu, Nianyin Zeng, Yurong Liu, and Fuad E. Alsaadi. "A survey of deep neural network architectures and their applications." Neurocomputing 234 (2017): 11-26. 
20. Fagan, Joseph F. "The origins of facial pattern recognition." In Psychological development from infancy, pp. 83-113. Routledge, 2017.

21. Einav, Liran, Amy Finkelstein, Sendhil Mullainathan, and Ziad Obermeyer. "Predictive modeling of US health care spending in late life." Science 360, no. 6396 (2018): 1462-1465.

22. Sundaramurthy, A., \& Chitra, V. (2016). Big data gathering in wireless sensor network using hybrid dynamic energy routing protocol. BEST: International Journal of Management, Information Technology and Engineering (BEST: IJMITE), 4(4), 5968.

23. DeFries, John C., and David W. Fulker. "Multiple regression analysis of twin data." Behavior genetics 15, no. 5 (1985): 467473.

24. Agarwal, Apoorv, Boyi Xie, Ilia Vovsha, Owen Rambow, and Rebecca Passonneau. "Sentiment analysis of twitter data." In Proceedings of the workshop on languages in social media, pp. 30-38. Association for Computational Linguistics, 2011.

25. Sandryhaila, Aliaksei, and Jose MF Moura. "Big data analysis with signal processing on graphs: Representation and processing of massive data sets with irregular structure." IEEE Signal Processing Magazine 31, no. 5 (2014): 80-90.

26. Anselin, Luc, Ibnu Syabri, and Youngihn Kho. "GeoDa: an introduction to spatial data analysis." Geographical analysis38, no. 1 (2006): 5-22.

27. Nadeau, David, and Peter D. Turney. "A supervised learning approach to acronym identification." In Conference of the Canadian Society for Computational Studies of Intelligence, pp. 319-329. Springer, Berlin, Heidelberg, 2005. 